\title{
Differences in Parental Differential Treatment, Locus Of Control and Achievement Motivation among The First And Last Born.
}

\author{
Srishti R. Haldipur ${ }^{1}$, Reshma Murali ${ }^{2}$, Archana Patki ${ }^{3}$ \\ ${ }^{1}$ Post Graduate student, Department of Psychology, Shri. Maniben M.P.Shah Women's College of Arts and \\ Commerce, Mumbai. \\ ${ }^{2}$ Assistant Professor, Department of Psychology, Shri. Maniben M.P.Shah Women's College of Arts and Commerce, \\ Mumbai. \\ ${ }^{3}$ Professor and Head, Department of Psychology, Shri. Maniben M.P.Shah Women's College of Arts and Commerce, \\ Mumbai. \\ E-mail - srishti.haldipur@gmail.com
}

\begin{abstract}
Introduction: The aim of this research was to examine differences between first and last born individuals in areas of perceived levels of Parental Differential Treatment (PDT), Locus of Control (LOC) and Achievement motivation (AM). This research hypothesized that differences would be seen among first and last born individuals on variables of PDT, measured by Maternal and Paternal scales, LOC and AM.

Methodology: The sample set of the research, included 120 young adult participants between the age group of 18 -25 years, living in Mumbai, Chennai and Bangalore. These participants were selected using the purposive sampling method, which is a non-probability sampling procedure. It is where, the participants are selected because of some characteristic which they possess as in the present study, the biological relatedness between siblings, age-disparity, equal representation of birth order among two-dyad siblings (first and last born), non- separation of parents, shared childhood experiences and absence of any disability of a participant's sibling or self were screened for in the present study. The age spacing between the participants and their biological sibling was controlled to be between 1 to 4 years.

Results: Results of an independent samples $t$ test show that there was no statistically significant difference between the first born $(\mathrm{M}=3.38, \mathrm{SD}=.45, \mathrm{~N}=60)$ and last born individuals $(\mathrm{M}=3.36, \mathrm{SD}=.40, \mathrm{~N}=60)$ on the Maternal scale of the SIDE; $\mathrm{t}(118)=.254, \mathrm{p}>0.05$ two-tailed. It was noted that, the computed $t$ value of 0.254 was found to be non significant and hence, the differences in the two groups on Maternal Differential Treatment were found to be not significant. Thus, it could be inferred that the two groups felt equally favored by their mothers as compared to their siblings while growing up.

Conclusion: Results revealed of no significant differences between the first and last born individuals on variables of Parental Differential Treatment - Maternal and Paternal scales, and Achievement motivation scores. This may be attributed to several possible and plausible reasons such as birth order, family constellation, psychological birth order, child's perception of the role to be played and many more.
\end{abstract}

Key Words: Parental Differential Treatment, birth order, locus of control, achievement motivation, young adults.

(Paper received $-11^{\text {th }}$ May 2016, Peer review completed $-4^{\text {th }}$ July 2016, Accepted $-6^{\text {th }}$ July 2016) 


\section{INTRODUCTION}

A recent trend in the psychological realm of research can be seen with a number of papers focusing on empirically determining the effects of the ordinal position of one's birth on their intellectual capabilities, personality and also mental health. The present research proposes to contribute though in a small manner yet in an active form towards this new emerging area.

\section{The concept of birth order}

The concept of birth order has been highly mentioned under the branch of Individual Psychology, by its founder Alfred Alder, who formally raised the issue around the early 1900s. Although his ideas were published largely during the 1920s, Adler primarily spoke of birth order having an effect on the development of personality. He suggested that, the first born were subjected to an attitude where, they often became authoritarian and construed power as their natural right. This was seen typically as they were given more family responsibilities than later born and were expected to set an example. This was seen as a factor that could eventually develop feelings of insecurity around the possibility of being 'dethroned' by later born [1].

Thus, Alfred Adler's theory attempted to understand how family matters, by considering the order of when a child enters a family (Adler, 1964). Moreover, he also mentioned of birth order to be seen as a given point of the child's existence, a fact that was considered to create an imprint on the individual which was often recognizable even in adult life as a part of the adult personality [2].

The understanding of birth order differs across theorists. For example, authors have described two definitions of birth order: one, ordinal position, which refers to the actual order of birth of the siblings, and psychological position, which refers to the role the child adopts in his or her interactions with others. However, the current research primarily focuses only on the effect of the actual order of one's birth and considers only the population of the two sibling dyads i.e. the first and the last born individuals [3].

\section{Perspectives to study differences between first and last born individuals}

There may be several reasons behind such different findings across several studies as, birth order is said to have not only an impact on the experiences an individual has within his/her individual family, but also on "the distinctive characteristics possessed by individuals from each birth-order position are rooted in the different sets of relationship-related cognitions they tend to acquire". These cognitions that individuals develop from their perspective as children later form the foundation for future interactions with others, and thus result in a 'birth-order related set of cognitions and personality characteristics' [4].

\section{Parental Differential Treatment (PDT)}

Authors pointed out that, it a common fallacy that one may often indulge in is to consider that the children from the same family are exposes to the same environment. He also mentioned that though some aspects in the home setting are same for all children in the same home, the psychological situation of each child differs from that of others due to the order of their succession [5]; thus, highlighting the concept of nonshared environment at home between siblings. Santrok [6] also pointed out on the differences in birth order to be explained in terms of variations in interactions with parents with the unique experience of being in a particular position in the family. Thus, this dimension allows provides a psycho-social perspective towards understanding birth order related differences.

\section{Evolutionary Perspective}

Frank Sulloway [7], emphasized on the concept not only of interest to psychologists, but also biologists who have looked at how valid it is to assume that birth order is responsible for the course of development of a child's personality or intelligence. He revolved his explanations around the works of Charles Darwin, 
the revolutionary biologist who proposed the theory of evolution based in natural selection, took a stance that birth order must impact how an organism travels through life. He mentions that children do not inherit special genes for being first born or later born, rather they inherit only genes for engaging successfully in competition for parental investment, and this is what leads to differing traits amongst siblings who have very similar genes. He emphasised this based on a logical explanation saying, that all methods that worked for the firstborn would eventually spawn counterstrategies in the later born to promote their own success.

The present study examines the differences between the first and the last born individuals on several dimensions namely, Parental Differential Treatment, Locus of Control and Achievement Motivation.

The hypotheses framed by the researcher are as follows

1. There will be a difference between the first and the last born individuals on the dimension of Maternal Differential Treatment.

2. There will be a difference between the first and the last born individuals on the dimension of Paternal Differential Treatment.

3. A significant $\chi 2$ goodness of fit value would be obtained on the Locus of Control variable demonstrating that frequencies on the three categories are statistically different from what would be expected by chance.

4. There will be a difference between the first and the last born individuals on the dimension of Achievement Motivation.

\section{Birth order studies}

Adler extensively hypothesized that the child's position in the family creates specific problems that are handled by families generally in the same way, and such birth order experiences may reveal a characteristic personality pattern for each ordinal birth position. He further extended this to saying that, as the family group developed, different demands arose, and need-fulfilment was assigned to each child in order of birth where, the style of coping was never the same for any two children as the situation changes [8]. He spoke of personality differences across the different ordinal positions of birth, four positions as mentioned by Adler in the birth order of a family included; the firstborn, who spends some time as the only child in the family, during which he/she receives most attention and love from parents without a competitor. With the birth of the next child comes in competition and the firstborn feels envious and comes face to face with powerful emotions of deprivation. The firstborn is seen to be liable to use all possible means at his disposal to achieve his parent's love, because he may feel rejected by the parents. He also claimed that when firstborns reached adulthood they yielded to those in charge of them, but strictly control those under them [9].

He said that many firstborns learnt to imitate their parents and play the role of the parent, thus as a result develop responsibility and the desire to protect and help others. Firstborns also developed great skill in management and organization [10]. The middle child was described to be the one who races against the older sibling, without any chance of catching up, who simultaneously faced the younger sibling who is trying to catch up to him. They were said to hold great ambition and full of competitive spirit as he/she must compete over and over for attention and prove themselves [11]. The youngest born has been considered to be at the optimum position yet at a dicey position. For, other children have preceded him/her, but no one is running after them and those who preceded him already paved the way; the parents by then are seen to have acquired parental skills at the expense of the older siblings [12].

However, according to Adler, the only child was seen to be in the worst position for, if pampered, and has got used to receiving attention and having parents fulfil their demands not only affects them being independent and also may have difficulty in delaying gratification [13].

Another important element that Adler [14] emphasized was the, element of psychological birth order rather than ordinal birth order. He stated it to be, 'it is not the child's number in the order of successive births which influences his character, but the situation into which he is born and the way in which he interprets it'. One was a catalogue of captivating stories about the family life of historical figures. 
The second form of evidence was a meta-analysis of the large number of studies on personality and birth order. This meta-analysis of several hundreds of empirical studies regarding birth-order effects on personality [15], supported the idea that compared to firstborns, younger children were generally less conformist and more adventurous. With the backing of several research findings over the years, comes a plethora of variables often studied along with birth order.

\section{METHODOLOGY}

\section{Participants}

The sample set of the research, included 120 young adult participants between the age group of $18-25$ years, living in Mumbai, Chennai and Bangalore. These participants were selected using the purposive sampling method, which is a non-probability sampling procedure. A purposive Sample is one that is selected based on the knowledge of the population and the purpose of the study. It is where, the participants are selected because of some characteristic which they possess as in the present study, the biological relatedness between siblings, age-disparity, equal representation of birth order among two-dyad siblings (first and last born), non- separation of parents, shared childhood experiences and absence of any disability of a participant's sibling or self were screened for in the present study. The age spacing between the participants and their biological sibling was controlled to be between 1 to 4 years.

\section{Research Design}

An exploratory model of research design was employed by the researcher with the Independent Variable of this study being Birth-order operationalized to be the ordinal position of the participants in the two sibling dyads (i.e. first and last-born) and four Dependent Variables that include; Perceived Parental Differential Treatment as measured by the SIDE - Maternal and Paternal scales, Locus of Control and Achievement Motivation.

Thus, the research involves a 'Randomized Group Design' with one Independent Variable - Birth Order with two levels (First and Last born individuals) and Four Dependent Variables - Maternal Differential Treatment, Paternal Differential Treatment, Locus of Control and Achievement Motivation. A population size 120 participants was obtained after screening for controls in the study, and were exposed to all the Dependent Variables.

\section{Scales used in the study}

\section{The Sibling Inventory of Differential Experience (SIDE) - Maternal and Paternal Differential Treatment scale}

The SIDE [16] was designed as a quantitative measure of the perceptions of direct parental treatment of self and of the sibling on independent scales. The SIDE includes four categories of sibling differential experiences namely; Differential sibling interaction (24 items), Differential parental treatment (9 items), Differential peer characteristics (26 items), and Events specific to the individual (26 items). However, this study uses only the subscale scale of Differential Parental Treatment (Maternal and Paternal subscales) to determine perceived Parental Differential Treatment, where nine items on differential parental treatment, answered separately for mother and father interactions that assess two main factors: affection and control.

The current study looks at this variable from a retrospective perspective, that requires the participant to look back in general and report if they seem to have experienced differential treatment during childhood by their parents in comparison to their sibling.

This scale was administered on participants after seeking permission from its original authors. The scale requires the respondents to make direct comparisons between the way his/her parents treated them and their sibling on the same questionnaire. For each of these two dimensions, siblings could report that they 
are treated equally, a bit differently, or very differently. Each item is answered on a 5-point scale. The responses include: $1=$ toward sibling much more, $2=$ toward sibling a bit more, $3=$ same toward my sibling and me, $4=$ toward me a bit more and $5=$ toward me much more. Higher scores indicate more positive treatment of self, relative to sibling.

\section{Rotter's Locus of Control (LOC) scale}

The Locus of Control is a 29 item questionnaire developed by Julian B. Rotter [17] that later underwent constant revisions. It measures generalized expectancies for internal versus external control of reinforcement. People with an internal locus of control hold the belief that, their own actions determine the rewards that they obtain, while those with an external locus of control believe that their own behaviour doesn't matter much and that rewards in life are generally outside of their control. Scores on this scale, range from 0 to 13. A low score indicates an internal control while a high score indicates external control, while a score between 9 and 12 is In-between Locus of control. The scale also includes 2 filler items. The internal consistency reliability of this scale ranges is approximately 0.70 and the scale also holds a testretest reliability estimate that ranges from .50 to .80 . Moreover, the scale also displays a good level of discriminate validity. The scale has been reported to have good discriminant validity for the scale indicated by low correlations with such variables as intelligence, social desirability and political affiliation.

\section{The Ray-Lynn Achievement Motivation Scale}

The short form of the Ray-Lynn Achievement Motivation/Orientation scale, is a 14-item self-report measure of achievement motivation, based on the Ray Achievement Orientation Scale, which originally had 28 questions [18-19]. This scale was administered on participants after seeking permission from its original authors.

\section{RESULTS}

As can observed from the results of an independent samples $t$ test that, there was no statistically significant difference between the first born $(\mathrm{M}=3.38, \mathrm{SD}=.45, \mathrm{~N}=60)$ and last born individuals $(\mathrm{M}=3.36, \mathrm{SD}=.40$, $\mathrm{N}=60$ ) on the Maternal scale of the SIDE; $\mathrm{t}(118)=.254, \mathrm{p}>0.05$ two-tailed. The degrees of freedom is equal to the total group size (120) minus 2 (118). It was noted that, the computed $t$ value of .254 was found to be significant at the .800 level of significance (two-tailed), which was much greater than the expected value at the level of significance of $p<0.05$ level and hence, the differences in the two groups on Maternal Differential Treatment were found to be not significant. Thus, it could be inferred that the two groups felt equally favored by their mothers as compared to their siblings while growing up.

Table 1 - Mean Differences in Maternal differential treatment between the first and last born individuals

\begin{tabular}{|c|c|c|c|c|c|c|c|c|}
\hline Maternal & $\begin{array}{l}\text { Birth } \\
\text { Order }\end{array}$ & $\mathrm{N}$ & M & SD & SEM & t value & df & $\begin{array}{l}\text { Sig. (2 } \\
\text { tailed) }\end{array}$ \\
\hline Differential & First born & 60 & 3.3898 & .45491 & .05873 & $.254^{*}$ & 118 & 0.800 \\
\hline Treatment & Last born & 60 & 3.3699 & .40346 & .05209 & & & \\
\hline
\end{tabular}

As can observed from the results of an independent samples $t$ test, shows that there was no statistically significant difference between the first born $(\mathrm{M}=3.01, \mathrm{SD}=.39, \mathrm{~N}=60)$ and last born $(\mathrm{M}=3.06, \mathrm{SD}=.39$, $\mathrm{N}=60$ ) individuals on the Paternal scale of the SIDE (Daniels and Plomin, 1985); $\mathrm{t}(118)=-.769, \mathrm{p}>0.05$ two tailed. The degrees of freedom is equal to the total group size (120) minus 2 (118). It could be noted that, the computed $t$ value of -.769 was found to be significant at a .443 level of significance (two-tailed), which was much greater than the expected level of $p<0.05$ level of significance and hence, the differences in the two groups on Paternal Differential Treatment were found to be not significant. Thus, it could be 
inferred that the two groups felt that they were equally favored by their fathers as compared to their siblings while growing up.

Table 2 - Mean Differences in Paternal differential treatment between the first and last born individuals

\begin{tabular}{lllllllll|} 
Paternal & $\begin{array}{l}\text { Birth } \\
\text { Order }\end{array}$ & $\mathrm{N}$ & $\mathrm{M}$ & $\mathrm{SD}$ & $\mathrm{SEM}$ & $\mathrm{t}$ value & $\mathrm{df}$ & $\begin{array}{l}\text { Sig. }(2 \\
\text { tailed })\end{array}$ \\
$\begin{array}{l}\text { Differential } \\
\text { Treatment }\end{array}$ & First born & 60 & 3.0130 & .39461 & .05094 & $-.769^{*}$ & 118 & 0.443 \\
\cline { 2 - 9 } & Last born & 60 & 3.0685 & .39673 & .05122 & & & \\
\hline
\end{tabular}

A chi square of goodness of fit was computed, to derive if the distribution of locus of control was merely obtained by chance. On the basis of the present sample, locus of control was seen to vary significantly by birth-order, $\chi 2(2, \mathrm{~N}=120)=11.400, \mathrm{p}<0.05$ two-tailed, and was not due to chance. The degrees of freedom is equal to the product of total number of rows minus 1 and total number of columns minus 1 (2). Thus, the hypotheses; the membership to Internal, In-between and External locus of control diverge significantly from the results expected merely by chance, may be retained.

Table 3 - The observed and expected frequencies of participants on locus of control $(\mathrm{N}=120)$

\begin{tabular}{|ccccccc|}
\hline & $\begin{array}{c}\text { Observed } \\
\text { frequencies }\end{array}$ & $\begin{array}{c}\text { Expected } \\
\text { frequencies }\end{array}$ & Residual & $\chi^{2}$ & df & $\begin{array}{c}\text { Sig. (two } \\
\text { tailed) }\end{array}$ \\
\hline $\begin{array}{c}\text { Internal } \\
\text { Locus of } \\
\text { Control }\end{array}$ & 38 & 40.0 & -2.0 & $11.400 \mathrm{a}$ & 2 & $0.003^{*}$ \\
\hline $\begin{array}{c}\text { In between } \\
\text { Locus of } \\
\text { Control }\end{array}$ & 56 & 40.0 & 16.0 & & \\
\hline $\begin{array}{l}\text { External } \\
\text { Locus of } \\
\text { Control }\end{array}$ & 26 & 40.0 & -14.0 & & \\
\hline Total & 120 & & & \\
\hline Note: a. 0 cells $(0.0 \%)$ have expected frequencies less than 5. The minimum expected cell frequency is
\end{tabular}
40.0. ${ }^{*} \mathrm{p}<.05$ level two-tailed

As can observed from the results of an independent samples $t$ test, it can be seen that there was no statistically significant difference in Achievement Motivation between the first born $(\mathrm{M}=32.36, \mathrm{SD}=4.60)$ and last born $(\mathrm{M}=32.36, \mathrm{SD}=4.60)$ individuals; $\mathrm{t}(118)=0.00, \mathrm{p}>1.00$. The degrees of freedom is equal to the total group size (120) minus 2 (118). It could be noted that, the computed $t$ value of 0.00 was found to be significant at 1.00 level of significance, which was much greater than the expected level of $p<0.05$ level of significance and hence, the differences in the two groups on Achievement Motivation were not found to be significant. Thus, it could be inferred that the two groups were equal in terms of their levels of achievement motivation.

Table 4 - Mean Differences in Achievement Motivation between the first born and last born individuals

\begin{tabular}{lllllllll|}
$\begin{array}{lllllll}\text { Achievement } \\
\text { Motivation }\end{array}$ & $\begin{array}{l}\text { Birth } \\
\text { order }\end{array}$ & $\mathrm{N}$ & $\mathrm{M}$ & $\mathrm{SD}$ & $\mathrm{SEM}$ & $\mathrm{t}$ value & $\mathrm{df}$ & $\begin{array}{l}\text { Sig. (two } \\
\text { taied) }\end{array}$ \\
\cline { 2 - 9 } & First born & 60 & 32.3667 & 4.60275 & .59421 & 0.000 & 118 & $1.000^{*}$ \\
\cline { 2 - 9 } & Last born & 60 & 32.3667 & 4.54345 & .58656 & & & \\
\hline
\end{tabular}




\section{DISCUSSION}

The aim of this research was to examine differences between the first and last born individuals in areas of perceived Parental Differential Treatment (PDT), Locus of Control (LOC) and Achievement motivation (AM). Independent samples $t$ test results revealed of no significant differences between the first and last born individuals on variables of Parental Differential Treatment - Maternal and Paternal scales, and Achievement motivation scores. This may be attributed to several possible and plausible reasons.

For instance, birth order however, when defined in simple terms, refers to a person's place in the family. Some psychologists have further have gone ahead and even labelled it as the "family constellation." However in-fact, several research also focused on the concept of psychological birth order [20] that spoke of people not having the same ordinal and psychological birth order position that may be further studied.

Another view point could be attributed to findings of the present research [21]. She highlighted the effects that a spacing of less than one year has on the family environment and suggests that more favourable responses by the children which are caused by the parents treating the two siblings in a two for one manner, where the effort of giving the necessary attention and resources is minimized owing to the two siblings having very similar requirements.

Also, the results of the current study may also be linked with the findings of Kowal and Kramer [22] who have shown that children who perceived a justified nature of their parents' differential behavior generally experienced more positive appraisals about their sibling relationship. Graham [23] emphasized that, regardless of one's position in a family, there are many variables that influence a person both positively and negatively. Thus, the family construct of nuclear or joint set-up was not taken as a control. And hence, may have played a moderating role in defining PDT, and Achievement Motivation.

For instance, Booth and Kee [24] found that the first born in any family has been seen to have a higher probability of being in a small family than those children born later in the birth order. Also, the sibling configuration according to gender may also be seen as a contributing factor to the shared or non-shared differences between siblings.

The non-significant differences seen within the two groups of the present study could also be attributed to other variables such as socioeconomic status, race and ethnicity, and age of participants and hence need to be explored. Positive psychological variables such as general well-being, and resilience may also be needed to be simultaneously explored with the current study.

For example, Mukherjee [25] pointed out, that Locus of control significantly influenced general wellbeing of students, internally controlled students were found superior on general wellbeing than externally controlled students. Birth order of the students seems to have significant influence on general wellbeing where, the first born students were found higher on general wellbeing than later born students.

That is, it makes them less likely to perceive unequal treatment as an indication that they are less valued or loved by their parents. Moreover, according to some papers [26], a strong family orientation was usually related to a strong attachment to the family members. They also argued that family members in collectivistic societies have attitudes, feelings, and behaviours of loyalty, connectedness, obligations, responsibility, and solidarity for each other.

Thus, several factors that may be enlisted include, social attitudes, social behaviour, resilience, well-being, self-esteem, coping mechanisms, parenting styles, and psychological-birth order may be needed to be further explored to gain a more comprehensive picture about birth-order research.

\section{REFERENCES}

1. Zajonc RB, Markus GB. Birth order and intellectual development. Psychol Rev 1975;82(1):74-90.

2. Shulman BH, Mosak HH. Birth order and ordinal position: Two Adlerian views. J Individ Psychol 1977;33(1):114-20.

3. Ernst C, Angst J. Birth order: Its influence on personality. Springer Science \& Business Media; 2012.

4. Zweigenhaft RL, Von Ammon J. Birth order and civil disobedience: A test of Sulloway's "born to rebel" hypothesis. J Soc Psychol 2000;140(5):624-7. 
5. Boll T, Ferring D, Filipp SH. Perceived parental differential treatment in middle adulthood: curvilinear relations with individuals' experienced relationship quality to sibling and parents. J Fam Psychol 2003;17(4):472-80.

6. Kowal AK, Krull JL, Kramer L. Shared understanding of parental differential treatment in families. Soc Develop 2006;15(2):276-95.

7. Sulloway FJ. Born to rebel: Birth order, family dynamics, and creative lives. Pantheon Books; 1996.

8. Sulloway FJ. Birth order and evolutionary psychology: A meta-analytic overview. Psychol Inquiry 1995;6(1):75-80.

9. Rohde PA, Atzwanger K, Butovskaya M, Lampert A, Mysterud I, Sanchez-Andres A, Sulloway FJ. Perceived parental favoritism, closeness to kin, and the rebel of the family: The effects of birth order and sex. Evol Hum Behav 2003;24(4):261-76.

10. Paulhus DL, Trapnell PD, Chen D. Birth order effects on personality and achievement within families. Psychol Sci 1999;10(6):482-8.

11. Freese J, Powell B, Steelman LC. Rebel without a cause or effect: Birth order and social attitudes. Amer Sociol Rev 1999;1:207-31.

12. Leman K. The birth order book: Why you are the way you are. Revell; 2009.

13. Adler A, Brett C. Understanding life. Hazelden Publishing; 1998.

14. Boshier R, Walkey FH. Birth order and conservatism: An Adlerian myth?. Psychol Rep 1971;29(2):392-4.

15. Watkins CE. The individual psychology of Alfred Adler: Toward an Adlerian vocational theory. J Vocational Behav 1984;24(1):28-47.

16. Daniels D, Plomin R. Differential experience of siblings in the same family. Dev Psychol 1985;21(5):747-55.

17. Nowicki S, Strickland BR. A locus of control scale for children. J Consult Clin Psychol 1973;40(1):148-56.

18. Ray JJ. A quick measure of achievement motivation-validated in Australia and reliable in Britain and South Africa. Austr Psychol 1979;14(3):337-44.

19. Ray JJ. The comparative validity of Likert, projective, and forced-choice indices of achievement motivation. J Soc Psychol 1980;111(1):63-72.

20. Buunk BP. Personality, birth order and attachment styles as related to various types of jealousy. Personal Individ Diff 1997;23(6):997-1006.

21. Nyman L. The identification of birth order personality attributes. J Psychol 1995;129(1):51-9.

22. Kowal A, Kramer L. Children's understanding of parental differential treatment. Child Dev1997;68(1):11326.

23. Price J. Parent-child quality time does birth order matter? J Hum Resources 2008;43(1):240-65.

24. Booth AL, Kee HJ. Birth order matters: the effect of family size and birth order on educational attainment. J Population Econ 2009;22(2):367-97.

25. Mukherjee H, Mukherjee P. Locus of Control, Birth Order and Residence as predictors of General Wellbeing with special reference to Tripura. Int J Behav Res Psychol 2014;2(5):53-8.

26. Abdel-Khalek AM. Age and sex differences for anxiety in relation to family size, birth order, and religiosity among Kuwaiti adolescents. Psychol Rep 2002;90(3):1031-6.

\author{
Acknowledgements - Nil \\ Source of Funding - Nil \\ Conflict of Interest - Nil
}

